\title{
A Construção dos Papéis Parentais em Casais Homoafetivos Adotantes
}

\author{
Jéssica Moraes Rosa \\ Universidade Católica do Rio de Janeiro, RJ. Brasil. \\ Georges Daniel Janja Bloc Boris \\ Universidade de Fortaleza, CE. Brasil.
}

\author{
Anna Karynne Melo \\ Universidade de Fortaleza, CE. Brasil. \\ Manoel Antônio dos Santos \\ Universidade de São Paulo, SP. Brasil.
}

\begin{abstract}
Resumo: Este estudo teve por objetivo compreender como se dá a construção do papel parental em casais homoafetivos adotantes, considerando o contexto singular da adoção e suas implicações psicológicas, sociais e legais. Trata-se de um estudo descritivo e exploratório, do qual participaram dois adultos que se encontravam em união homoafetiva e que adotaram legalmente uma criança. Foram realizadas entrevistas semiestruturadas, com roteiro que abordava questões direcionadoras à investigação do desejo de ter filhos, os trâmites legais da adoção e a transição para a parentalidade. Os dados foram submetidos à análise temática, balizada pela compreensão da questão de pesquisa: a assunção do papel parental. Emergiram os seguintes temas: tomando a decisão de adotar; tecendo narrativas da adoção; aprendendo a exercer os papéis parentais; organizando a rotina doméstica. Os resultados apontam para uma definição mais igualitária de papéis parentais na família homoafetiva. A construção desses papéis, ainda que sofra influência cultural, é uma elaboração criativa da díade conjugal e da família que se constitui. Ficou evidenciado que os papéis parentais tendem a ser incorporados e exercidos de formas peculiares nas famílias homoafetivas constituídas pela via da adoção. Palavras-chave: Homossexualidade, Adoção (Criança), Papel dos Pais, Relações Pai-Criança.
\end{abstract}

\section{The construction of Parental Roles in Homosexual Adopting Couples}

\begin{abstract}
This study aimed to understand how the construction of the parental role in homosexual couples adopting is, considering the unique context of adoption and their psychological, social and legal implications. This is a descriptive, exploratory study, which involved two adults being in a homo-affective union and legally who adopted a child. Semi-structured interviews with a script addressing the desire to have children, and the legal procedures of adoption and of the transition to the parenthood were conducted. The data were subjected to thematic analysis, guided by the research question: the assumption of the parental role. The following topics emerged: taking the decision to adopt; weaving narratives of adoption; learning to exercise parental roles; and organizing the domestic routine. The results point to a more egalitarian definition of parental roles in homo-affective families. The construction of these roles, still suffering cultural influence, is a creative elaboration of the marital dyad and the family. We conclude that parental roles tend to be incorporated and exercised in peculiar ways by homoaffective families formed through adoption.

Keywords: Homosexuality, Adoption (Child), Parental Role, Father Child Relations.
\end{abstract}




\title{
La Construcción de los Roles de los Padres en las Parejas Homosexuales que Adoptan
}

\begin{abstract}
Resumen: Este estudio tuvo como objetivo comprender cómo es la construcción del rol de padres en las parejas homosexuales que adoptan, teniendo en cuenta el contexto único de la adopción y sus implicaciones psicológicas, sociales y legales. Se trata de un estudio exploratorio descriptivo, que involucró a dos adultos que estando en unión homo-afectiva, legalmente adoptaron a un niño. Se realizaron entrevistas semiestructuradas que investigaron el deseo de tener hijos, y los procedimientos legales de la adopción y de la transición a la paternidad. Los datos fueron sometidos a análisis temático, modulado por la comprensión de la pregunta de investigación: la asunción del papel de los padres. Emergieron los siguientes temas: tomar la decisión de adoptar; tejer narrativas de la adopción; aprender a ejercer funciones de los padres; y organizar la rutina doméstica. Los resultados apuntan a una definición más igualitaria de los roles de los padres en la familia homo-afectiva. La construcción de estos papeles, que sufren la influencia cultural, es una elaboración creativa de la díada conyugal y de la familia que se forma. Quedó evidenciado que los roles de los padres tienden a ser incorporados y que estos se ejercen de manera peculiar en las familias homo-afectivas constituidas a través de la adopción.

Palabras clave: Homosexualidad, Adopción (Niño), Rol de los padres, Relaciones Padre-Niño.
\end{abstract}

\section{Introdução}

A estrutura familiar sofreu modificações ao longo da história, em decorrência, principalmente, das transformações ocorridas nas sociedades e culturas (Castells, 1999; Poster, 1979; Wagner, 2011). Hoje, não podemos mais nos referir à família como um modelo normatizado e padronizado, uma vez que existem diferentes configurações familiares. Entre os arranjos familiares contemporâneos situam-se as famílias monoparentais, pluriparentais e homoafetivas (Uziel, 2007). Neste estudo adotaremos o termo "homoafetividade" para nos referirmos ao relacionamento afetivo-sexual entre pessoas do mesmo sexo, embora mantenhamos o uso de termos como homossexualidade e homossexuais quando referirmos estudos extraídos da literatura da área.

As uniões homoafetivas ganharam espaço crescente nos embates sociais e na luta pelos direitos dos homossexuais de constituírem famílias, o que culminou com a conquista do direito à união estável sendo reconhecido pelo Supremo Tribunal Federal (STF) em 2011. Nessa decisão histórica, o STF contribuiu para que se reformulasse o conceito de família no contexto nacional, garantindo direitos e deveres aos parceiros do mesmo sexo que decidem dar fundamento jurídico às suas uniões. Essa decisão legal reafirmou o desejo de constituir família a partir do reconhecimento social da legitimidade dessas uniões.
Embora a questão da prole tenha ficado à margem da sentença do STF, os casais homoafetivos já há algum tempo vêm reivindicando seu direito a formar famílias, tanto pela incorporação de filhos que sejam frutos dos relacionamentos heterossexuais anteriores de um dos parceiros, ou que sejam viabilizados pelo acesso às novas tecnologias de reprodução assistida, ou ainda pela possibilidade de adoção (Uziel, 2007).

Partimos de perguntas-chave para elaboração do presente estudo, tais como: será que a rearrumação sexualidade/desejo de ter filhos gera estranhamento social quando casais homoafetivos buscam constituir família? Se até há bem pouco tempo o exercício da sexualidade era associado à procriação e as funções parentais eram claramente definidas para cada gênero, como esses papéis são construídos nas novas configurações familiares, formadas por dois pais ou duas mães?

Buscamos compreender como se dá a construção dos papéis parentais em casais homoafetivos adotantes. Por papel parental entendemos as descrições, percepções e atitudes com relação ao papel social, psicológico, comportamental ou emocional dos pais. Para alcançarmos o objetivo traçado, buscamos apresentar e descrever historicamente as modificações das estruturas familiares; bem como reconhecer o percurso histórico e conceitual da homossexualidade 
à homoafetividade, enfatizando as diferenças entre gênero, sexo e sexualidade, que, com suas características próprias, influenciaram as representações sociais da homossexualidade (Boris, 2002).

\section{Família: definição e evolução histórica}

Ao investigar a história da família, enfatizando a das famílias ocidentais, os estudos concluem que elas sofreram modificações, ou poderíamos nomeá-las como adaptações às mudanças sociais (Poster, 1979; Wagner, 2011). Sendo assim, deveríamos considerar o termo família não no singular, e sim no plural, uma vez que nos encontramos inseridos em uma diversidade social do conceito de família. Por outro lado, e da mesma forma que o significado de família, entendemos que a compreensão das características dos relacionamentos amorosos deve ser associada à época, cultura e ao grupo social (Nunes, 2008).

Em seu livro Teoria crítica da família, Poster (1979) divide historicamente as famílias em quatro principais grupos: a família burguesa (século XIX), a família aristocrática (séculos XVI e XVII), a família camponesa (séculos XVI e XVII) e, por fim, a família da classe trabalhadora, característica do período da Revolução Industrial. Cada uma dessas famílias possui características próprias, suficientemente nítidas para defini-las e delimitar seus contornos, o que nos permite compreender as mudanças evolutivas familiares que antecederam as atuais.

Poster (1979) assinala que a família burguesa, ou família nuclear burguesa, apresenta-se como o modelo tradicional de família nas sociedades patriarcais, sendo o arranjo dominante na sociedade capitalista. Trata-se de uma estrutura familiar privada e autônoma, separada da sociedade, na qual o lar é um espaço de lazer e os pais exercem uma relação de poder para com os filhos, o marido é a figura de maior autoridade da casa e a mãe tipicamente é aquela que exerce o papel de cuidadora dos filhos e do lar.

Deparamos, atualmente, com novas configurações familiares, diferentes da tradicional família nuclear burguesa, composta pela união de um homem e uma mulher, como define Costa (1999) em seus estudos. Nesse contexto de mudança, os pares homoafetivos representam uma das novas formas de arranjos familiares, assim como as famílias monoparentais, caracterizadas pela criação de uma criança por um dos pais sem um companheiro; e asfamílias pluriparentais ou recompostas, resultado, principalmente, de divórcios e separações (Uziel, 2007).
Para Wagner (2011), as novas composições familiares devem ser entendidas como reflexo das transformações sociais, que ampliam não apenas o conceito de família, como também suas implicações na sociedade. A ampliação do conceito de família e, portanto, a legitimação de seus diversos formatos, não implica na falência dessa instituição. Devemos pensar, então, em uma crise do modelo tradicional de família, e não em uma crise da instituição familiar, que apesar de seu rearranjo continua sendo uma das instituições mais vigorosas e vigentes na sociedade.

Apesar da crise do modelo nuclear, o desejo de constituir uma família que gere descendentes pode perpassar as diferentes constituições familiares. A abrangência desse desejo se torna ainda mais exequível, dados os avanços proporcionados pela tecnologia e as novas legislações que possibilitam o acesso à parentalidade para aqueles que são impedidos de, biologicamente, gerar descendentes (Uziel, 2007). Ser pai ou ser mãe, na atualidade, independe do casamento ou até mesmo da união consensual. Sendo assim, como citado anteriormente, deparamos com as famílias monoparentais, nas quais um pai ou uma mãe cria sozinho(a) um filho; com as famílias pluriparentais, que trazem à tona a distinção entre a concepção, de ordem biológica, e a filiação, de ordem social e afetiva; e, por fim, com as famílias homoparentais. Essa ainda desperta na população um forte estranhamento, apesar de ser um movimento que vem ganhando espaço nos últimos anos. De acordo com Uziel (2007), o termo famílias homoparentais foi criado na década de 1990 por homens e mulheres que buscavam uma definição para suas famílias constituídas por não heterossexuais.

\section{Gênero, sexo e homossexualidade}

Pensar o gênero masculino e feminino vai além da distinção biológica ou sexual. Implica também uma distinção no plano sociocultural, pois é nas relações sociais que construímos as distinções nos papéis atribuídos a cada gênero, que implicam, inclusive, em diferenças culturais, políticas e econômicas. Segundo Boris (2002), a essência da sexualidade tende a ser entendida a partir dos atributos físicos e reprodutivos de cada sexo - masculino e feminino - e, portanto, não são considerados os elementos subjetivamente elaborados por cada indivíduo, a partir de sua vivência histórico-cultural em sociedade. Sendo assim, definir o sujeito - e, por conseguinte, seus papéis sociais - a partir do sexo é limitante, pois se deixa de lado a idiossincrasia de cada indivíduo. 


\section{Rosa, Jéssica Moraes; Melo, Anna Karynne; Boris, Georges Daniel Janja Bloc; Santos, Manoel Antô- nio dos (2015). Papéis Parentais em Casais Homoafetivos.}

Socioculturalmente, exercemos papéis que estão predefinidos de uma forma tradicional e, portanto, cultural, e que determinam nossa maneira de ser e agir nas relações sociais e familiares, pois são percebidos como naturais e por isso, esperados por outros pela expectativa lançada, tanto sobre a atuação dos homens quanto das mulheres, como afirma Bourdieu (1999). Alterar para: As características biológicas são, assim, definidoras de papéis, pois trata-se do 'fundamento epistemológico dos preceitos sociais' (Boris, 2002, p. 16), segundo o qual a heterogeneidade dos sexos garantiria os direitos e deveres diferenciados de homens e mulheres".

A noção de gênero distingue-se da concepção de sexo, porque vai além da prática sexual e, dessa forma, do domínio dos aspectos biológicos; envolve a investigação das atitudes, comportamentos, relações, valores, estereótipos, conceitos e preconceitos, além de seu caráter histórico, social e político, construídos culturalmente (Boris, 2002). Segundo Muraro e Boff (2002), conceituar gênero implica ir além da antinomia feminino/masculino e, portanto, do registro biológico. Trata-se de compreender como as diferenças foram construídas historicamente. Sendo assim, falar de gênero é "falar a partir de um modo particular de ser no mundo, fundado, de um lado, no caráter biológico do nosso ser e, de outro, nas dimensões da cultura, da história, da sociedade, da ideologia e da religião desse caráter biológico" (Muraro, \& Boff, 2002, p. 18).

O termo "homossexualismo", consolidado no contexto da medicina científica que estava sendo sistematizada no século XIX, tem o sufixo "ismo" a indicar que se concebia a homossexualidade como uma condição anômala, um desvio da normativa sexual (Foucault, 1989). Porém, estudos científicos da segunda metade do século XX mostraram que a homossexualidade não deveria ser compreendida como doença, distúrbio ou perversão, ou ainda como desvio ou transtorno sexual. Em 1973 foi excluída como categoria do DSM-III pela Associação Americana de Psiquiatria (Nucci, \& Russo, 2009). No Brasil, somente em 1999 o Conselho Federal de Psicologia ratificou a normalidade da homossexualidade, condenando teorias homofóbicas e intervenções terapêuticas para "conversão" à heterossexualidade. Apesar desse reconhecimento, as diferentes expressões da homofobia ainda se fazem presentes na atualidade (Fundação Perseu Abramo, 2009), porém as homossexualidades vêm conquistando progressivamente seus direitos de cidadania por meio das lutas sociais (Mott, 2006). No âmbito legal uma das bandeiras mais evidentes do movimento homossexual é a luta pelo direito à adoção.

\section{Adoção}

As famílias romanas pertenciam a um sistema patriarcal, na qual cabia ao pai tomar as decisões importantes sobre a família, inclusive quanto à entrada de novos membros, desde as crianças das filhas até os escravos. Assim, naquele contexto cultural, era frequente a adoção de membros estranhos a fim de garantir a perpetuação do culto doméstico. As pessoas inseridas no contexto familiar eram, assim, subordinadas ao domínio de um pater familias. A adoção era consumada, portanto, a partir da vontade e do poder absoluto do pai (Moreno, 2009; Neuburger, 1999).

Com o advento do cristianismo, a adoção passou a objetivar a criação artificial de laços de filiação. Para assemelharem-se às leis da natureza, foram criadas regras, como a exigência de uma diferenciação de idade entre adotantes e adotados (Moreno, 2009). Mais tardiamente, com as guerras, as crianças órfãs eram adotadas como um meio de reparação social, a fim de que as mesmas encontrassem um lugar na sociedade. Adotar passou, então, a ser uma ação que beneficiava tanto adotado quanto adotantes, por possibilitar a ambos a construção de uma família (Neuburger, 1999). Atualmente, segundo Schettini, Amazonas e Dias (2006), a maior demanda da adoção é oriunda de casais jovens inférteis, porém casais com filhos biológicos, casais na meia idade, assim como casais homoafetivos e pessoas solteiras têm manifestado interesse na adoção para constituir ou ampliar sua família.

Ainda que seja crescente a busca de casais homoafetivos pela adoção, são escassos os estudos endereçados a esse tema no contexto brasileiro. Isso possivelmente se deve ao tabu que ainda ronda essa temática, apesar da transição histórica e cultural que vivemos. No Brasil, a Constituição de 1988, no art. 1723, Livro IV, Título III, reconhece como entidade familiar a união estável entre um homem e uma mulher, configurada na convivência pública, contínua e duradoura e estabelecida com o objetivo de constituição de família (Brasil, 1988). Na primeira parte do artigo vimos que a Constituição exclui a união conjugal dos pares homoafetivos como família, consequentemente, o direito à adoção de crianças pelos parceiros do mesmo sexo não é legitimado. No Estatuto da Criança e do Adolescente - ECA (Brasil, 1990) e na Nova Lei da Adoção não se encontra um artigo que proíba a adoção em qualquer configuração familiar. 
A restrição se refere a que uma das partes adote individualmente a criança, pois, seguindo as diretrizes da Constituição Federal no tocante à instituição familiar, compreende-se que basta que exista um, assumindo um papel parental e sua prole, para que se configure uma unidade familiar (Brasil, 1988).

O reconhecimento da união estável como família legítima pelo Código Civil, vigente para casais heterossexuais, permitiu uma reestruturação do conceito de família, uma vez que foram reconhecidas aquelas organizações familiares que antes viviam à margem do direito, moldando-se à realidade social. De outra parte, em maio de 2011, o STF reconheceu a união estável para casais do mesmo sexo, o que significa na prática que esses casais estão submetidos às mesmas obrigações e cautelas impostas para os casais heterossexuais, como, por exemplo, direito à pensão por morte e benefícios previdenciários, recebendo a proteção do Estado.

Segundo o ECA, toda criança ou adolescente tem direito a ser criado e educado no seio da sua família e, excepcionalmente, em família substituta, o que caracteriza as famílias adotivas. Sendo assim, a adoção consiste em uma medida protetiva à criança e ao adolescente, garantindo-lhes o direito de um convívio familiar sadio. Cabe ao Estado, portanto, por meio do Poder Judiciário e do Ministério Público, autorizar o estabelecimento e a destituição das relações de filiação e parentalidade (Uziel, 2007). Ou seja, é garantido ao Estado retirar crianças e adolescentes em situações de risco de suas famílias de origem, ou reinseri-los em sua família biológica, ou ainda, em uma nova instituição familiar.

O Tribunal de Justiça do Rio de Janeiro (Rio de Janeiro, 2012) define a adoção como o rompimento do todo o vínculo jurídico entre a criança/adolescente e sua família biológica, fazendo com que esta perca todos os direitos e deveres em relação àquela, e vice-versa. $O$ registro civil de nascimento original é cancelado, sendo elaborado um novo, no qual constarão os nomes dos adotantes, garantindo aos adotados os mesmos direitos de um filho biológico, o que reduz ou anula as diferenças entre um filho concebido pela via da consanguinidade ou agregado por laços socioafetivos. A idade mínima para se adotar é 21 anos e o estado civil é irrelevante aos olhos da lei. $\mathrm{O}$ adotante deverá ser, no mínimo, 16 anos mais velho do que o adotado. Caso este tenha idade superior a 12 anos, a adoção deverá ocorrer mediante sua expressa concordância.
O processo de habilitação dos adotantes para a adoção implica na intervenção multidisciplinar do psicólogo e do assistente social, que constituem a equipe técnica que auxiliará a decisão do juiz e a preparação da família para o acolhimento do adotado. Nesse contexto, um desafio que tem emergido na contemporaneidade é a solicitação de adoção dirigida ao Judiciário por casais homoafetivos. Essa nova demanda exige a produção de novos conhecimentos nesse campo emergente da Psicologia Judiciária. Este estudo teve por objetivo compreender como se dá a construção do papel parental em casais homoafetivos adotantes, considerando o contexto singular da adoção e suas implicações psicológicas, sociais e legais.

\section{Método}

Trata-se de um estudo descritivo e exploratório, de cunho qualitativo, baseado em pesquisa de campo, utilizando como delineamento metodológico o estudo de caso.

\section{Participantes}

Foram incluídos no estudo dois participantes, sendo um do sexo feminino (56 anos) e o outro do sexo masculino (39 anos). Ambos encontravam-se em união estável com seus parceiros e realizaram a adoção por vias legais. A primeira participante provinha de um casal constituído por duas mulheres, cuja companheira tinha 39 anos. O casal vivia em união consensual havia 22 anos, tendo se casado legalmente há cinco meses. Adotaram uma menina recém-nascida (com 20 dias), que, no momento da entrevista, tinha 17 anos. O segundo participante era o cônjuge mais velho de um casal constituído por dois homens, cujo companheiro tinha 21 anos. Eles estavam juntos havia três anos, com união estável de dois anos. Adotaram dois filhos, uma menina de oito anos (no momento da entrevista, com nove anos) e um menino com dois meses de idade (por ocasião da pesquisa, com um ano). Os participantes da pesquisa eram pessoas pertencentes a um estrato socioeconômico médio.

O critério para definir o número de participantes se baseou nos pressupostos da amostragem de conveniência. Considerando que se trata de um fenômeno que, apesar de se mostrar crescente, ainda é de difícil acesso, em decorrência, principalmente, da invisibilidade que cerca as uniões homoafetivas em nossa realidade, o delineamento metodológico privilegiou a inclusão de informantes-chave, sendo um prove- 


\section{Rosa, Jéssica Moraes; Melo, Anna Karynne; Boris, Georges Daniel Janja Bloc; Santos, Manoel Antô- nio dos (2015). Papéis Parentais em Casais Homoafetivos.}

niente de união homoafetiva entre duas mulheres e o outro, entre dois homens.

\section{Instrumento}

Foi utilizado como instrumento de investigação um roteiro de entrevista semiestruturada, especialmente elaborada para esse estudo, com questões relativas à formação do vínculo afetivo entre os cônjuges, desejo de adotar, facilidades e barreiras encontradas no percurso da adoção e transição para a parentalidade. No presente relato será feito um recorte que inclui as questões relacionadas ao modo como se deu o processo de adoção, como os participantes percebiam a construção dos papéis parentais, e com quais facilidades/dificuldades se depararam durante a definição desses papéis.

\section{Procedimentos}

O projeto de pesquisa foi aprovado pelo Comitê de Ética em Pesquisa da instituição a qual está vinculada a pesquisadora. Para selecionar os participantes seguiu-se a estratégia da "bola de neve". Pessoas conhecidas e amigos em comum sugeriram nomes de potenciais participantes, que foram contatados por telefone e consentiram com a inclusão na pesquisa.

Foram agendados encontros em locais escolhidos pelos próprios participantes, de acordo com sua conveniência. Nos encontros buscamos explicar o objetivo da pesquisa e, em seguida, os participantes assinaram os Termos de Consentimento Livre e Esclarecido. Solicitamos a permissão dos entrevistados para que, durante a entrevista, fosse utilizado um gravador. Cada entrevista teve duração média de uma hora e trinta minutos.

Posteriormente, as entrevistas audiogravadas foram transcritas na íntegra e o material resultante constituiu o corpus de análise. Para interpretar os dados e explicitar as percepções dos participantes acerca da assunção ao papel parental, utilizou-se a técnica de análise de conteúdo na modalidade temática (Bardin, 1977). Foram percorridas as três etapas operacionais pertinentes à análise temática: pré-análise, exploração do material e tratamento/interpretação dos resultados obtidos.

Primeiramente, realizou-se uma leitura exaustiva e flutuante do corpus. A seguir, os dados foram agrupados segundo as unidades de registro que emergiram do material empírico, tendo como eixo condutor o objetivo do estudo. A partir dessa etapa, foram selecionados trechos do material considerados relevantes à constituição das unidades de significação, dando origem aos temas e subtemas. Estes foram codificados e organizados, conforme a similaridade de conteúdos, em categorias temáticas.

Para preservar o anonimato dos participantes e manter a confidencialidade dos dados, os nomes próprios foram substituídos por nomes fictícios. O projeto foi aprovado pelo Comitê de Ética em Pesquisa da instituição acadêmica, protocolo $n^{\circ}$ 0870/2008.

\section{Resultados e discussão}

Da análise das falas dos entrevistados emergiram os temas e subtemas que deram origem às categorias de análise, pautadas no objetivo da pesquisa, ou seja, a assunção ao papel parental no contexto do processo de adoção por casais homoafetivos. Foram elaboradas as seguintes categorias: (1) construindo a decisão de adotar; (2) tecendo narrativas da adoção, dividida nas seguintes subcategorias: legalização; dificuldades enfrentadas na adoção; (3) aprendendo a exercer os papéis parentais, com as subcategorias: influência do ambiente na construção dos papéis parentais; dificuldades encontradas ao se tornarem pais/mães; enfrentando preconceitos; e (4) organizando a rotina doméstica.

\section{(1) Construindo a decisão de adotar}

Os motivos que levam uma pessoa, ou um casal, a adotar são inúmeros, e estão relacionados não apenas à reparação de um casal impedido de procriar, mas também, a um "modo de reparação de famílias, respondendo a uma dupla necessidade: estabelecer uma descendência para assegurar a transmissão do patrimônio, e se preocupar com o repouso da alma dos pais, com a transmissão da lembrança" (Neuberger, 1999, p. 73). Segundo Moreno (2009), 63\% dos brasileiros que praticam a adoção são motivados pela ausência de filhos biológicos. Trata-se do desejo de constituir uma família, com a presença de um filho, que possa dar continuidade à linhagem familiar.

A entrevistada, a que designaremos como Luisa, refere que ela e sua parceira não demonstravam interesse em ter filhos de imediato:

\footnotetext{
Não estava nos meus planos, pelo menos naquele momento não estava nos meus planos [...] eu não me via como mãe, não tinha a ideia de ser mãe, eu achava que quem poderia ser mãe era ela [parceira], mas seria uma coisa para o futuro (Luisa, 56 anos).
}

A criança que adotaram foi deixada na porta de sua casa, com cerca de 20 dias de nascida. Na mesma 
noite decidiram que ficariam com o bebê: "Na mesma noite a gente tomou a decisão de ficar com ela, de não levar na delegacia, de não levar a canto nenhum, porque o normal seria a gente comunicar, nê".

Segundo Salomé, Espósito e Moraes (2007), as uniões homoafetivas não objetivam, primeiramente, a geração de filhos, mas sim assegurar o vínculo de amor, o respeito, o carinho e o cuidar do outro. A base da motivação para a constituição desse arranjo familiar não está pautada na procriação, mas na troca de afetos entre os parceiros.

Já o entrevistado do sexo masculino (Carlos) reconhece que o desejo de adotar remontava a uma década: "Sempre tinha vontade, eu não posso ter filho, desde há mais de dez anos, quando eu descobri que eu não podia ter filho...". Carlos e o parceiro deram entrada ao processo judicial, porém a criança que viriam a adotar não fazia parte da lista de adoção do processo do qual estavam aguardando o desfecho. Como relata:

Eu tive que passar por dentro, eu sempre ia por fora, mas nesse dia eu fui por dentro do pátio [abrigo], estavam todas as crianças lá [...] aí foi quando eu conheci, que ela chegou até a mim. Aí quando ela chegou até a mim dizendo: 'Oi, tio', não sei o quê, aquela coisa toda, ai eu disse: Não, outro dia o tio vem lhe buscar, então, pronto, fui pra casa [...] quando eu cheguei na porta do abrigo ela estava no portão, aí quando ela me viu ela disse: 'Ah, tio, não acredito, tu veio me buscar!' Aí, pronto, aquilo ali me comoveu, foi aquela coisa, não fui eu que escolhi, ela que me escolheu (Carlos, 39 anos).

Ao questionarmos o entrevistado por que ele e companheiro decidiram que aquele era o momento de adotar, ele respondeu:

Desde o início a gente pensava em segmentos, de fazer tudo direitinho, na nossa união estável, a gente deu entrada no processo de mudança de união estável para a união civil [...] e a gente seguiu todos os trâmites: o namoro, relacionamento, a gente foi morar junto, depois a gente decidiu fazer a união estável, logo quando saiu, no outro dia a gente procurou um cartório, já fizemos, tudo direitinho, com testemunha, aquela história todinha que a lei pede, né? Aí o próximo passo eram os filhos, né? (Carlos, 39 anos).
Asfalas sugerem a observância cautelosa da exigência sociocultural da necessidade de cumprir etapas para o alcance gradual de uma finalidade maior: a construção dos alicerces da família. As uniões matrimoniais possuem, historicamente, o caráter de gerar ganhos mútuos e status social, devido à união entre duas famílias distintas, além de ser um meio de gerar filhos legítimos (Fernandes, 2010). Essas características resultaram, culturalmente, no estabelecimento de regras e normas que, independentemente do tipo de união (heterossexual ou homossexual), influenciam o relacionamento conjugal. A cobrança social tende a exigir dos indivíduos um casamento que resulte no nascimento de descendentes. Trata-se, enfim, da coexistência de valores e padrões tradicionais, que funcionam como mediadores que atribuem os papéis sociais de cada gênero.

Segundo Silva Neto, Strey e Magalhães (2011, p. 46), a conjugalidade é estabelecida a partir de fatores subjetivos, que fortalecem "identidades valorizadas socialmente"; assim, o status relacionado ao casamento é promovido nos grupos sociais, ou seja, é transmitida intergeracionalmente a importância da constituição de uma família. Segundo Teófilo (2003), a conjugalidade presente nos casais heterossexuais está sendo também um comportamento habitual dos casais homoafetivos, assim como a aspiração pela paternidade e maternidade. Observa-se nos relatos dos participantes que, dada a inexistência de modelos alternativos à família baseada na heteronormatividade, a fonte primordial de inspiração para a vida conjugal e familiar dos homossexuais ainda é a família monogâmica, nuclear e centrada no casal parental heterossexual.

\section{(2) Tecendo narrativas da adoção}

A adoção é um processo que, na maioria das vezes, beneficia tanto a criança adotada - por garantir-lhe uma família, um lar onde receberá cuidados e suporte afetivo -, quanto os pais adotantes, pois lhes oportuniza a realização de ter um filho (Lipp, Mello, \& Ribeiro, 2011). Segundo os autores, trata-se de um movimento que inscreverá a criança no processo de filiação, no qual ela poderá encontrar um lugar de reconhecimento e pertencimento a um contexto familiar, na medida em que, ao autorizarem uma adoção, os pais exprimem seu desejo pelo filho. Por outro lado, a adoção não consiste em um processo restrito apenas ao nível psicológico, pois se dá, principalmente, no plano jurídico/social. Tais aspectos, aliás, são bastante enfocados nas falas dos participantes, conforme veremos a seguir. 


\section{Rosa, Jéssica Moraes; Melo, Anna Karynne; Boris, Georges Daniel Janja Bloc; Santos, Manoel Antô- nio dos (2015). Papéis Parentais em Casais Homoafetivos.}

\subsection{Legalização}

Ao solicitar uma adoção, os adotantes devem passar por uma série de trâmites legais, como apresentar a documentação solicitada, realizar as entrevistas com a equipe técnica (psicólogo e assistente social) e receber a visita desses profissionais no domicílio. Uma vez considerados habilitados, os pretendentes à adoção devem aguardar até que chegue sua vez no cadastro. Quando isso ocorre, é concedida à família a guarda provisória da criança (Brasil, 1990).

Ia vir a assistente social fazer uma visita [...] uma psicóloga, ver a nossa condição de criar a criança, para poder a adoção ser deferida realmente. Então tudo ia ser analisado, se a gente tinha uma estrutura familiar, se a gente tinha uma estrutura financeira, com condições favoráveis à criança (Luisa, 56 anos).

No entanto, antes de darem início ao processo, cabe ao casal decidir no nome de quem será solicitada a guarda da criança, pois, como a Constituição Federal (Brasil, 1988) não reconhece a união entre duas pessoas do mesmo sexo como casamento civil, não é garantida a estas a opção de registrarem a criança no nome dos dois.

"Não era permitido adotar uma criança duas pessoas do mesmo sexo. Não era permitido, né? Então ou eu ou ela teríamos que adotar num nome só, então ficou no meu nome" (Luisa, 56 anos).

\subsection{Enfrentando dificuldades na adoção}

Apesar de o Tribunal de Justiça do Rio de Janeiro (Rio de Janeiro, 2012) informar que, ao contrário do que muitos afirmam, o processo de adoção é simples e rápido, as falas dos entrevistados contradizem essa declaração:

E depois eu entrei com uma ação de adoção, demorou em torno de um ano, mais ou menos, demorou aí um ano, porque aí tem os trâmites, né? (Luisa, 56 anos).

A gente está esperando a justiça, né? Porque demora e a gente também tem que esperar. Mas a gente já... eu soube de casos que tem crianças que esperam quatro anos, três, aí vai depender da vara, do juiz, do juizado, essa história todinha (Carlos, 39 anos).

Além da demora do processo, os participantes também relataram que se depararam com outras dificuldades no processo de adoção:
Eu acho muito burocrático o processo de adoção, eu acho que muita gente não adota porque é burocrático. [...] eu acho que deveria ser uma coisa mais fácil (Carlos, 39 anos).

Em relação à lei, ela é muito... Eu acho assim, a lei é muito lenta, porque não é como falam, por exemplo, nas redes sociais, na televisão, não é bem daquela forma: "Ah, você vai lá, você entra na fila de adoção, tem não sei quantas mil crianças pra adotar", mas não é bem daquela forma, como se você chegasse, entrasse na fila e você já saísse com a criança, né? Tem vários critérios, até você entrar nos critérios... E às vezes você chega a criar seus próprios critérios, porque você não... muitas pessoas não esperam a justiça, chegam e vão por debaixo dos panos, e metem a cara e vão, tá entendendo? E às vezes dá certo, às vezes não dá, e aí vai depender da, às vezes, da sorte. Na verdade é sorte, porque às vezes não dá certo (Carlos, 39 anos).

Silva, Mesquita e Carvalho (2010) afirmam que uma das maiores dificuldades vivenciadas pelos candidatos durante o processo é a burocracia exigida pelo Estado para a legalização da adoção. O que acaba por desencorajar ou mesmo impedir que alguns casais possam consumar o desejo de adotar. Além disso, outros fatores costumam funcionar como barreiras, como o medo da hereditariedade desconhecida e o temor de que os filhos adotivos sejam problemáticos, rebeldes e que não superem o trauma de terem sido abandonados. Esses temores perpassam alguns casais antes de tomarem a decisão de adotar. Dias, Silva e Fonseca (2008) afirmam que é por acreditarem que as crianças mais velhas carregam a lembrança do passado, desde sonhos a frustrações e traumas vivenciados, que os casais buscam com maior frequência adotar bebês.

Os participantes não referiram esses mitos e preconceitos, que são comuns no cenário da adoção por pessoas heterossexuais. Para os entrevistados é a criação dada aos filhos que garante ou não que este venha a apresentar problemas psicológicos no futuro:

Não é por ser adotivo que vai dar problema, é a criação, eu entendo assim, sabe? (Luisa, 56 anos).

Tem a história dos genes, porque a criação é o que completa, eles vieram de onde vieram, mas cabe a mim e a ele a criação, pra completar o ciclo, porque 
se a gente acompanhar os genes não vai ser bom, então se eles vieram à gente tem o dom da transformação, então a gente já transformou muita coisa (Carlos, 39 anos).

Na fala de Carlos nota-se uma permeabilidade ao discurso do senso comum que enfatiza a carga de hereditariedade negativa que o adotado traria ("porque se a gente acompanhar os genes não vai ser bom").

\section{(3) Aprendendo a exercer os papéis parentais}

A paternidade engendrada no contexto da adoção é perpassada por um estigma. Muitas vezes, ela é entendida como inferior à biológica e, para alguns, é compreendida como um vínculo fictício paterno (Andrade, Costa, \& Rosseti-Ferreira, 2006). Na adoção homoafetiva, além do tabu que diz respeito à compreensão social da adoção como inferior à filiação biológica, os casais defrontam-se com uma outra barreira social relacionada à homoparentalidade, que se define pela intitulação de um adulto como pai ou mãe de uma criança (Uziel, Cunha, \& Torres, 2007).

Estudos indicam que não é possível comprovar alguma deficiência ou vantagem na criação de crianças por casais homoafetivos, pois seu desenvolvimento depende da inserção em um ambiente harmonioso e da disponibilidade dos pais em oferecerem os cuidados necessários em relação aos filhos. Sendo assim, acredita-se que é o vínculo estabelecido entre adotantes e adotados que determinará a qualidade de suas relações, independentemente da orientação sexual dos pais (Silva, Mesquita, \& Carvalho, 2010; Teixeira Filho, 2010; Uziel, Cunha, \& Torres, 2007).

Os entrevistados evidenciaram em suas falas que estão disponíveis e atentos às necessidades dos filhos, visando a garantir qualidade dos cuidados oferecidos. Na percepção tanto do pai como da mãe, foi possível estabelecer vínculos sólidos e fortes com seus filhos:

A noite a gente sempre tá em casa juntos, finais de semana a gente sempre tá juntos, pra sair, pra passear. [...] Porque a gente tem muito aquela coisa de família, de mesa posta, a gente toma café da manhã, almoça juntos, janta juntos, ter ao menos alguma refeição durante o dia, porque devido ao trabalho, né, a gente é muito corrido, a gente tem que pelo menos fazer alguma refeição juntos os quatro, eu, o M. [filho] no braço, ela e o Luis [parceiro], então a gente procura sempre, pra poder criar um vínculo na cabeça dela (Carlos, 39 anos).

Tá ali junto, pro que der e vier, a gente coloca muito à $V$. [filha] como é maior a questão do amigo, a gente vê as famílias hoje em dia, a gente não vê a questão do amigo, o filho amigo da mãe ou amigo do pai, tem um amigo fora, e a gente hoje, a gente tem sempre aquela coisa presente de não mentir, de dizer, de falar, de dizer o que quer (Carlos, 39 anos).

Solicitamos aos entrevistados que nos informassem quando se sentiram pai e mãe pela primeira vez:

No dia que ela chamou de pai, a ficha ainda não tinha caído, por enquanto eu era tio, mas no dia que ela me chamou de pai, pronto (Carlos, 39 anos).

Com o crescimento dela [...] as idas ao médico [...] e aí você começa a levar pro médico e você começa a sentir aquele papel de mãe, né? (Luisa, 56 anos).

Questionamos a eles se percebiam que, tratandose de dois sujeitos do mesmo sexo, eles conseguiam assumir as atividades tradicionalmente associadas aos papéis socialmente estabelecidos de pai e de mãe, e se ainda acreditavam que era realmente necessário assumir esses papéis na criação dos filhos.

Eu acho que não o papel de pai e mãe, sabe? Mas eu acho que a gente dá pra suprir as necessidades dela. Não vou dizer que seja um papel de pai e mãe, porque o papel de pai e mãe é difícil. Você dizer que dois homens ou duas mulheres possam dar a uma criança o papel de pai e mãe. [...] eu acho que depende muito da criança, depende muito do casal, eu acho que a gente tem suprido a necessidade dela (Luisa, 56 anos).

Hoje em dia os direitos estão tão assim, o homem cozinha, a mulher cozinha, o homem trabalha, a mulher trabalha, então, assim, tá natural, porque hoje em dia tanto o homem faz tudo, como a mulher também faz tudo. [...] Pra gente, em relação a isso também foi muito bom, porque a relação pai e mãe também na cabeça deles ficou boa, pra eles entenderem [...] relação assim, porque geralmente na família a mulher, a responsabilidade é da mulher de cuidar. Por exemplo, a V. pergunta assim: "Pai, é o senhor que vai me deixar hoje ou pai, é o senhor que vai me deixar hoje?" A questão 


\section{Rosa, Jéssica Moraes; Melo, Anna Karynne; Boris, Georges Daniel Janja Bloc; Santos, Manoel Antô- nio dos (2015). Papéis Parentais em Casais Homoafetivos.}

das responsabilidades, mas a questão agora do ser humano materno e paterno, acho que pela questão dos sentimentos, das atitudes, que às vezes a mulher tem que ter, por exemplo, no caso da V. ser mulher, a gente ter que ensinar a higiene, comportamento, sentar de perninha cruzada, comer, por exemplo, comer de garfo e faca. [...] Assumimos os papéis, sem nenhum problema, tiramos de letra (Carlos, 39 anos).

Os papéis sociais são resultantes de construções históricas. Desde tempos imemoriais homens e mulheres iniciaram os acordos de cooperação nas tarefas domésticas, os primeiros eram responsáveis pela caça, enquanto as mulheres, reservadas à gravidez, cuidavam dos filhos e do preparo das carnes (Fernandes, 2010). As mudanças ocorridas, principalmente na segunda metade do século XX, decorrentes de um processo de modernização social, econômica e cultural, alteraram algumas características do funcionamento familiar, principalmente no que diz respeito às tarefas pertencentes a cada gênero. A entrada da mulher no mercado de trabalho inaugura um novo papel, o de profissional, enquanto é exigido do homem que divida as tarefas relacionadas aos afazeres domésticos, inclusive assumindo um papel mais ativo no cuidado e educação dos filhos (Santos, Caldana, \& Biasoli-Alves, 2001). Essas mudanças nas tarefas outorgadas a cada gênero nos permitem pensar que um casal (heterossexual ou homossexual) pode assumir todas as tarefas necessárias à criação de um filho, independentemente de seu sexo e orientação sexual. Nesse sentido, é possível identificar uma certa naturalização dos papéis de gênero na fala dos entrevistados.

\subsection{Influência do ambiente na construção dos papéis parentais}

Não se pode pensar que a construção dos papéis parentais se dá apenas nas relações diretas estabelecidas entre adotantes e adotados. O meio externo apresenta uma forte influência no estabelecimento desses papéis. Segundo Andrade et al. (2006), a paternidade, seja ela adotiva ou biológica, é construída a partir dos discursos e práticas sociais de sua época. O amor materno, que exige abnegação total da mãe em prol de seus filhos, foi uma construção social que vigorou em determinado período, resultado da compreensão de como deveriam ser as famílias. Nesse sentido, seria ingenuidade não considerar a influência desses fatores para a construção do ser mãe e do ser pai em cada contexto histórico, inclusive no que diz respeito ao assumir certas responsabilidades voltadas aos cuidados com a criança.

Acho que a minha família, a própria família que di-
zia: a sua mãe é ela, né? E ela ficou me reconhecendo
mais como mãe, embora ela aceite que ela (parceira) é
tanto mãe quanto eu (Luisa, 56 anos).

Na escola [...] quer falar com a mãe dela, da criança, aí se eu não pudesse ela ia [...] contatava primeiro eu, pelo fato do registro estar no meu nome, mas também tinha a autorização de que, caso eu não pudesse, ela contatava a outra (Luisa, 56 anos).

\subsection{Dificuldades encontradas ao se tornarem pais e mães}

Poucas foram as dificuldades percebidas depois que se tornaram legalmente responsáveis pelas crianças. A transição para a parentalidade foi vivenciada pelas famílias como um acontecimento único e gratificante.

\begin{abstract}
A única dificuldade que a gente teve foi pra trabalhar. Vinha a preocupação de saber com quem a gente iria deixar, então, como a gente sempre foi resolvido em relação a isso, a gente não quis botar uma babá em casa, uma empregada [...] então a primeira coisa que a gente fez foi se organizar no trabalho, pra poder dar conta da vida pessoal, porque o casal também precisa da vida pessoal, e agora, no nosso caso, que a gente tem dois filhos, a gente procurou adaptar as nossas intimidades às crianças, porque à sociedade a gente já tinha, porque nós somos dois homens que são casados (Carlos, 39 anos).
\end{abstract}

Assim, eu não achei nenhuma dificuldade, nem na parte financeira, nem na parte de responsabilidades. [...] Nós nos adaptamos bem [...] não tenho nenhum problema com ela, nunca tive, até hoje, e acredito que não vou ter (Luisa, 56 anos).

A criação de uma criança envolve um conjunto de aspectos relacionados: ao ambiente de interação social, que tem como base o vínculo estabelecido entre pais e filhos, e ao ambiente didático e disciplinar, que corresponde ao estabelecimento de normas e regras de conduta (Prado, Piovanotti, \& Vieira, 2007). Para os participantes, a educação da criança em um lar homoafetivo não difere essen- 
cialmente da criação nas famílias convencionais. O pai e a mãe entrevistados priorizam a qualidade do cuidado parental para o desenvolvimento dos filhos. Esse cuidado implica uma série de responsabilidades dos pais, que se tornam desafios sob quaisquer circunstâncias.

\subsection{Enfrentando preconceitos}

Apesar de estar se tornando uma prática que, gradualmente, vem ganhando espaço e reconhecimento por parte da sociedade, a adoção por casais homoafetivos ainda gera desconforto, espanto e descrença. Como toda experiência nova, ainda paira grande desconfiança em relação à competência de gays e lésbicas para se tornarem pais (Uziel et al., 2007). Carlos relatou que ele e o companheiro sofrem preconceitos em relação à adoção devido à sua sexualidade:

"Quando a gente chega em alguns lugares, algumas pessoas se chocam, né? Quando veem dois homens chegando com duas crianças" (Carlos, 39 anos). Já Luísa referiu que nunca foi discriminada:

\footnotetext{
"Não sofremos nenhum tipo de preconceito até hoje. Que eu saiba não, se alguém falou alguma coisa por aí não chegou até mim, também eu não dou muita importância, sabe?" (Luisa, 59 anos).
}

Suas respostas nos fazem refletir sobre a coexistência de perspectivas diferentes. A primeira fala indica um estranhamento social quando se dá visibilidade à família homoafetiva com filhos. A segunda fala explicita uma possível tolerância social quanto à adoção por casal homoafetivo feminino, possivelmente por cumprirem com a expectativa social de que mulheres são "naturalmente" as pessoas mais adequadas para educarem crianças. Esse achado corrobora a literatura. Segundo Palma e Levandowski (2008), há uma mudança social, ainda que lenta e gradual, na forma de pensar e agir diante da homossexualidade feminina.

\section{(4) Organizando a rotina doméstica}

Segundo Teófilo (2003), os casais homoafetivos, em decorrência da influência cultural que legitima unicamente a orientação heterossexual, buscam como parâmetros de relacionamentos os casais heterossexuais. Desse modo, tendem a seguir os modelos tradicionais, inclusive no que diz respeito à divisão dos afazeres domésticos e aos cuidados dos filhos.
Ao se referirem à organização da rotina doméstica, os participantes relataram com frequência uma divisão de tarefas que é estabelecida a partir da disponibilidade de cada um para determinada situação:

\begin{abstract}
Se eu estiver de folga em casa, ele vai trabalhar. A gente reveza, tem uma pessoa que ajuda a gente, mas a responsabilidade da casa é nossa, a responsabilidade da organização, dos meninos, de levar pro colégio, dar comida do M., [...] de fazer mercantil, de lavar a roupa, né? Arrumar a casa, fazer comida, é toda minha e dele. A gente concilia isso bem, a gente se organiza, né? E no final do dia tudo dá certo, é compensador. [...] É de acordo com nosso tempo, o nosso trabalho, né? Porque a gente sempre faz o seguinte: a gente concilia as folgas, no dia que eu tô de folga, eu fico; no dia que eu tô trabalhando, ele fica. É assim, a gente reveza (Carlos, 39 anos).
\end{abstract}

Segundo Prati e Koller (2011), a inserção de um filho, seja por via da adoção ou não, produz uma alteração no funcionamento dos casais e/ou famílias, permitindo que os pais se ajustem ao momento específico que estão vivendo. O ajustamento abarca, inclusive, as tarefas assumidas por cada cônjuge. O êxito dessa adaptação depende da forma como os pais trabalham juntos nos seus papéis de pais, o que é definido pelos autores como coparentalidade. Provavelmente por dividirem as responsabilidades intituladas "maternas" e "paternas", os participantes encontram facilidade em flexibilizar as tarefas a partir de suas disponibilidades, em vez de fixarem com rigidez os papéis e obrigações de cada um.

\section{Considerações Finais}

Este estudo buscou compreender as percepções da construção dos papéis parentais em casais homoafetivos que adotaram crianças. Os dados permitiram identificar as rotinas vividas por esses casais, seu relacionamento com os filhos, além das dificuldades que enfrentaram ou que ainda enfrentam tanto no processo de adoção, quanto na criação das crianças.

Os relatos obtidos mostram que os participantes percebem que a criação dos filhos independe da orientação afetivo-sexual dos casais, pois compreendem que o necessário é que a criança desenvolva um vínculo saudável com seus pais - sejam eles adotantes ou não. Também é enfatizada a importância de que os cônjuges busquem preservar um relacionamento 


\section{Rosa, Jéssica Moraes; Melo, Anna Karynne; Boris, Georges Daniel Janja Bloc; Santos, Manoel Antô- nio dos (2015). Papéis Parentais em Casais Homoafetivos.}

de qualidade entre eles, fortalecido por uma aliança baseada no amor, no carinho e no respeito mútuo.

Os dogmas culturais que procuram enquadrar os indivíduos homossexuais em estereótipos sociais, associando-os a patologias e anormalidade (Uziel, 2007), tendem a alimentar preconceitos infundados, principalmente quando se trata de um casal que decide ter um filho. Essas ideias preconcebidas podem influenciar as decisões de juízes no que tange ao deferimento dos pedidos de adoção, principalmente pela inexistência de legislação específica que regulamente a adoção por pares homoafetivos. Por outro lado, não existem indícios que comprovem que filhos de pais homoafetivos tendam a apresentar algum comprometimento em seu desenvolvimento que possa ser associado a essa condição.

Quanto aos papéis parentais, as entrevistas apontaram que sua construção é resultado de um processo que se inicia na decisão/desejo de adotar, sendo apropriados pelo sujeito adotante a partir dos vínculos estabelecidos com o adotado. O desenvolvimento desses papéis é influenciado diretamente pelo ambiente externo, que pode (ou não) reconhecer aquela pessoa como pai ou mãe. Cabe ressaltar que, ainda que as tarefas atribuídas pela cultura a cada gênero tenham se modificado nas últimas décadas, já que hoje os papéis sociais do homem e da mulher são flexíveis e estabelecidos pelo sujeito em suas relações, ainda existe uma cobrança social em torno dessas atribuições. Tal exigência pode influenciar o preconceito que questiona se um casal homoafetivo teria as condições necessárias para educar uma criança.

Ao mesmo tempo, os entrevistados parecem ter incorporado alguns estereótipos de gênero, o que sugere que também eles não saem ilesos das marcas culturais. Cabe enfatizar que suas falas, em alguns pontos,

\section{Referências}

Andrade, R. P., Costa, N. R. A, \& Rosseti-Ferreira, M. C. (2006). Significações de paternidade adotiva: um estudo de caso. Paidéia (Ribeirão Preto), 16(34), 241-252. doi:10.1590/S0103-863X2006000200012 Bardin, L. (1977). Análise de conteúdo. Lisboa: Edições 70.

Boris, G. D. J. B. (2002). Falas de homens: a construção da subjetividade masculina. São Paulo, SP: Annablume. divergem, enquanto que em outros são congruentes. Ao serem questionados sobre os papéis de mãe e pai estabelecidos socioculturalmente para cada gênero, Luisa acredita ser muito difícil um casal homoafetivo assumir esses papéis, ao passo que Carlos tem outra compreensão dessa questão, pois acredita que ele e seu parceiro perpassam tanto pelo papel materno quanto paterno, sem reificá-los e sem fixá-los em um ou outro. Por outro lado, as respostas convergem quando ambos afirmam dividir suas funções em relação aos filhos e às atividades domésticas de acordo com suas disponibilidades, sem que haja uma rigidez nessa distribuição dos afazeres. Esse fato mostra que a definição de papéis parentais, ainda que sofra influência cultural, é também uma construção e adaptação criativa da díade conjugal e da família que se constitui. Os papéis, portanto, tendem a ser aprendidos e desempenhados de formas particulares na família homoafetiva constituída pela via da adoção.

Por fim, podemos destacar a relevância deste estudo, que agrega conhecimentos a uma área que, apesar de estar despertando o interesse dos pesquisadores atualmente, ainda é escassa em termos de investigações sistemáticas. Associamos essa escassez de estudos às dificuldades inerentes a um campo relativamente novo, como o recrutamento de sujeitos. No processo de elaboração da pesquisa deparamo-nos com pessoas que se recusaram a ser entrevistadas e instituições que não aceitavam questionar seus membros se os mesmos tinham interesse em participar. Outra dificuldade é a pouca produção teórica específica para o contexto das famílias homoafetivas, que resulta em uma limitação para a compreensão da homoparentalidade. Apesar dessas barreiras, acreditamos que outros estudos possam contribuir para lançar luz sobre esse fenômeno em expansão.

Bourdieu, P. (1999). A dominação masculina (M. H. Kuhner, Trad.). Rio de Janeiro, RJ: Bertrand Brasil.

Brasil. (1988). Constituição da República Federativa do Brasil de 1988. Recuperado de http://www.planalto.gov.br/ccivil_03/constituicao/ConstituicaoCompilado.htm

Brasil. (1990). Lei no 8.069, de 13 de julho de 1990. Dispõe sobre o Estatuto da Criança e do Adolescente e dá outras providências. Diário Oficial da União, 27 
de setembro de 1990. Recuperado de http://www. planalto.gov.br/ccivil_03/leis/L8069.htm

Castells, M. (1999). O fim do patriarcalismo: movimentos sociais, família e sexualidade na era da informação. In Castells, M. (Org.), O poder da identidade (K. B. Gerhardt, Trad.). São Paulo, SP: Paz e Terra.

Costa, J. (1999). Ordem médica e norma familiar. Rio de Janeiro, RJ: Graal.

Dias, C. M. S. B., Silva, R. V. B., \& Fonseca, C. M. S. M. S. (2008). A adoção de crianças maiores na perspectiva dos pais adotivos. Contextos Clínicos, 1(1), 28-35. Recuperado de http://revistas.unisinos.br/ index.php/contextosclinicos/article/view/5475

Fernandes, A. R. (2010). O poder nas relações conjugais: uma investigação fenomenológica sobre as relações de poder no casamento. São Paulo, SP: Annablume.

Foucault, M. (1989). História da sexualidade 1: a vontade de saber (Albuquerque \& Guilhon, Trad.). Rio de Janeiro, RJ: Graal.

Fundação Perseu Abramo (2009). Diversidade sexual e homofobia no Brasil: intolerância e respeito às diferenças sexuais. Recuperado de http://novo. fpabramo.org.br/content/diversidade-sexual-e -homofobia-no-brasil-intolerancia-e-respeitodiferencas-sexuais

Lipp, L. K., Mello, A. B. G., \& Ribeiro, M. M. S. M. (2011). O Patinho Feio no imaginário parental. Ágora: Estudos em Teoria Psicanalítica, 14(2), 275-291. doi:10.1590/S1516-14982011000200008

Moreno, A. Z. (2009). Adoção: práticas jurídicas e sociais no Império Luso-Brasileiro (XVIII-XIX). História (São Paulo), 28(2), 449-466. doi:

Mott, L. (2006) Homo-afetividade e direitos humanos. Revista Estudos Feministas, 14(2), 509-521. doi:10.1590/S0101-90742009000200015

Muraro, R. M., \& Boff, L. (2002). Feminino e masculino: uma nova consciência para o encontro das diferenças. Rio de Janeiro, RJ: Sextante.

Neuburger, R. (1999). O mito familiar (S. Rangel, Trad.). São Paulo, SP: Summus.

Nucci, M. F., \& Russo, J. A. (2009). O terceiro sexo revisitado: a homossexualidade nos Archives of Sexual Behavior. Physis: Revista de Saúde Coletiva, 19(1), 127-147. doi:10.1590/S0103-73312009000100007

Nunes, L. A. (2008). Expectativas de jovens solteiros universitários frente ao casamento: um estudo descritivo [Dissertação de Mestrado]. Universidade de Fortaleza, Fortaleza, CE.
Palma, Y. A., \& Levandowski, D. C. (2008). Vivências pessoais e familiares de homossexuais femininas. Psicologia em Estudo, 13(4), 771-779. doi:10.1590/S1413-73722008000400015

Poster, M. (1979). Teoria crítica da família (A. Cabral, Trad.). Rio de Janeiro, RJ: Zahar.

Prado, A. B., Piovanotti, M. R. A., \&Vieira, M. L. (2007). Concepções de pais e mães sobre o comportamento paterno real e ideal. Psicologia em Estudo (Maringá), 12(1), 41-50.

Prati,L.E., \&Koller, S.H. (2011). Relacionamento conjugal e transição para a coparentalidade: perspectiva da psicologia positiva. Psicologia Clínica, 23(1), 103-118. doi:10.1590/S0103-56652011000100007

Rio de Janeiro (Estado). (2012), Poder Judiciário. Procedimentos para adoção. Recuperado de http://www. tjrj.jus.br/web/guest/institucional/inf-juv-idoso/ cap-vara-inf-juv-idoso/adocao/procedimentos

Salomé, G. M., Espósito, V. H. C., \& Moraes, A. L. H. (2007). O significado de família para casais homossexuais. Revista Brasileira de Enfermagem, 60(5), 559-563. doi:10.1590/S0034-71672007000500014

Santos, M. C., Caldana, R. H. L., \& Biasoli-Alves, Z. M. M. (2001). O papel masculino dos anos quarenta aos noventa: transformações no ideário. Paidéia (Ribeirão Preto), 11(21), 57-68. doi:10.1590/S0103-863X2001000200007

Schettini, S. S. M., Amazonas, M. C. L. A., \& Dias, C. M. S. B. (2006). Famílias adotivas: identidade e diferença. Psicologia em Estudo (Maringá), 11(2), 285-293. doi:10.1590/S1413-73722006000200007

Silva, L. A., Mesquita, D. P., \& Carvalho, B. G. E. (2010). Investigando o processo de adoção no Brasil e o perfil dos adotantes. Revista de Ciências Humanas, 44(1), 191-204. doi:10.5007/2178-4582.2010v44n1p191

Silva Neto, J. A., Strey, M. N., \& Magalhães, A. S. (2011). Sobre as motivações para a conjugalidade. In A. Wagner et al. (Orgs.), Desafios psicossociais da família contemporânea: pesquisas e reflexões. Porto Alegre, RS: Artmed.

Teixeira Filho, F. S. (2010). Os segredos da adoção e o imperativo da matriz bioparental. Revista Estudos Feministas, 18(1), 241-262. doi:10.1590/S0104-026X2010000100015

Teófilo, M. C. C. (2003). Casais de homens: um estudo fenomenológico da conjugalidade homoerótica 
Rosa, Jéssica Moraes; Melo, Anna Karynne; Boris, Georges Daniel Janja Bloc; Santos, Manoel Antônio dos (2015). Papéis Parentais em Casais Homoafetivos.

masculina [Dissertação de Mestrado]. Universidade de Fortaleza, Fortaleza, CE.

Uziel, A. P. (2007). Homossexualidade e adoção. Rio de Janeiro, RJ: Garamond.

Uziel, A. P., Cunha, C. S., \& Torres, I. (2007). Homoparentalidade: estratégia política e cotidiano. Omertaa: Journal for Applied Anthropology, 118-125. Recuperado de http://www.omertaa.org/archive/omertaa0015.pdf

Wagner, A. (2011). Desafios psicossociais da família contemporânea: pesquisas e reflexões. Porto Alegre, RS: Artmed.

\section{Jéssica Moraes Rosa}

Mestranda em Psicologia Clínica pela Pontifícia Universidade Católica do Rio de Janeiro, Rio de Janeiro-RJ. Brasil.

E-mail: jessicamrpsi@gmail.com

\section{Anna Karynne Melo}

Doutora em Saúde Coletiva pela Universidade Federal do Ceará, Fortaleza - CE. Docente da Universidade de Fortaleza, Fortaleza-CE. Brasil.

E-mail: karynnemelo@unifor.br

\section{Georges Daniel Janja Bloc Boris}

Doutor em Sociologia pela Universidade Federal do Ceará, Fortaleza - CE. Docente da Universidade de Fortaleza, Fortaleza-CE. Brasil.

E-mail: geoboris@uol.com.br

\section{Manoel Antônio dos Santos}

Doutor em Psicologia Clínica pela Universidade de São

Paulo, São Paulo - SP. Docente da Universidade de São

Paulo, São Paulo - SP. Brasil.

E-mail: manoelmasantos@gmail.com

Endereço para envio de correspondência: Universidade de Fortaleza, Diretoria do Centro de Ciências Humanas, Psicologia, Av. Washington Soares, 1321. Edson Queiroz. CEP: 60811-341. Fortaleza-CE. Brasil.

Recebido 25/07/2014

Aprovado 20/01/2016

Received $07 / 25 / 2014$

Approved 01/20/2016

Recibido 25/07/2014

Aceptado 20/01/2016

Como citar: Boris, G. D. J., Rosa, J. M., Melo, A. K., \& Santos, M. A. (2016). A Construção dos Papéis Parentais em Casais Homoafetivos Adotantes. Psicologia: Ciência e Profissão, 36(1): 210-223. doi:10.1590/1982-3703001132014

How to cite: Boris, G. D. J., Rosa, J. M., Melo, A. K., \& Santos, M. A. (2016). The construction of parental roles in homosexual adopting couples. Psicologia: Ciência e Profissão, 36(1): 210-223. doi:10.1590/1982-3703001132014

Cómo citar: Boris, G. D. J., Rosa, J. M., Melo, A. K., \& Santos, M. A. (2016). La construcción de los roles de los padres en las parejas homosexuales que adoptan. Psicologia: Ciência e Profissão, 36(1): 210-223. doi:10.1590/1982-3703001132014 